\title{
MERRE TOVÁBB KISTÉRSÉGEK? KEREKASZTAL BESZÉLGETÉS
}

\section{Konferencia beszámoló}

\author{
(Belügyminisztérium, Budapest, 2005. október. 4.)
}

\section{LIESZKOVSZKY JÓZSEF - REISINGER ADRIENN}

A kistérség fogalmi rendszere hazánkban az 1990-es évek első felében került újra középpontba. A kistérségi rendszer kialakításának szükségessége elsősorban az európai uniós csatlakozás miatt kerủlt a figyelem középpontjába. 1996-tól 2003-ig a KSH által kijelölt 150 kistérség múködött Magyarországon. 2003-ban új kistérségi lehatárolás született, melynek alapján ma 168 kistérség múködik hazánkban. Müködésuiket 2004-tỏl törvény szabályozza, a 2004. évi CVII. törvény a települési ỏnkormányzatok többcélú kistérségi társulásáról melléklete tartalmazza a kistérségek felsorolását. Fontos kiemelni, hogy a kistérségi rendszer a rendszerváltás után kialakult önkormányzati-megyei felosztás keretein belül mủködik. Az Európai Unió térszerkezeti lehatárolásának megfelelỏen a hazai kistérségek a NUTS4 kategóriába tartoznak.

$\mathrm{Az}$ említett törvény a következőképpen fogalmazza meg a kistérségek feladatkörét: „1. § (1) A kistérségben - kivéve a fővárost és azt a kistérséget, amelyben egy település alkot egy kistérséget - mủködő települési önkormányzatok képviselötestületei (a továbbiakban: képviselö-testület) a kistérségi együttmúködés hosszú távú biztosítására írásbeli megállapodással (a továbbiakban: többcélú kistérségi társulási megállapodás) a kistérségben egy többcélú kistérségi társulást alakíthatnak. A többcélú kistérségi társulás részt vehet a kistérség területének összehangolt fejlesztésében (különösen: fejlesztési tervek, programok, pályázatok készítésében, megvalósításában) és a településfejlesztés összehangolásában, vállalhatja kistérségi közszolgáltatások biztosítását, fejlesztését és szervezését, valamint intézmények fenntartását." (2004. évi CVII. törvény)

Feltehető a kérdés, hogy miért kerültek a figyelem középpontjába a kistérségek az 1990-es évek folyamán? Alapvetően 3 tényezỏ említhető meg ${ }^{1}$ :

- A kilencvenes évek során világossá vált, hogy a kialakult önkormányzati rendszer nem tartható fent változatlan formában, a szétaprózottság helyett előtérbe kerülttek az önkormányzati együttmúködések, társulások formái

- Felismerték, hogy bizonyos feladatok sokkal hatékonyabban oldhatók meg társulások formájában.

- Az európai uniós csatlakozással előtérbe került a régió, mint területi egység kérdése. 
A kistérségi társulási rendszer létrehozásának föbb céljai többek között a következỏk:

- a közszolgáltatások javítása;

- a térbeli gondolkodás elösegítése mikroszinten;

- a társadalmi és területi különbségek mérséklése;

- a nagy ellátórendszerek reformja.

Ahhoz, hogy a kistérségi társulási rendszer hatékonyan tudjon müködni, illetve, hogy hazánk megfeleljen az európai uniós csatlakozás során felmerülő újabb közigazgatási feladatoknak, a Belügyminisztérium létrehozta az IDEA Programot, melynek keretében kijelölték a közigazgatás fejlesztésének fö irányait. A középpontban az önkormányzati rendszer önállóságának megtartása és a kistérség, város, régió szerepének meghatározása és a térbeli gondolkodás kialakítása áll. A Programról részletes információk a következö internetes oldalakon érhetök el: www.idea.gov.hu, illetve a www.b-m.hu/idea.

Az IDEA Program keretében került sor a „Kistérségi kerekasztal” beszélgetésre, amelynek során a téma szakértơi összefoglalták a kistérségi együttmüködés során eddig megszerzett tapasztalataikat, a jövő feladatait. Az előadásokat követő vita során megfogalmazódtak további kérdések, feltevések.

A bevezetö előadást Lamperth Mónika belügyminiszter tartotta. Elöször ismertette a kistérség, mint tervezési-statisztikai területfejlesztési egység történetét a kezdetektöl napjainkig. A bevezetést követően az elöadás fố témája a települési önkormányzatok többcélú kistérségi társulási rendszerének kialakítása és azok eddig elért eredményei voltak. A Kormány a kistérségi társulási rendszer kialakításakor több fontos célt tủzött $\mathrm{ki}$, mint a közszolgáltatások javítása, azokhoz egyenlö eséllyel való hozzájutás, illetve az összefogásra ösztönzés vagy a társadalmi és területi különbségek mérséklése (innen is ered a többcélú név).

Jelenleg hazánkban 152 többcélú, 11 területfejlesztési célú kistérség található, három kistérségben a társulás alakulása folyamatban van, kettőben (a budapesti és a debreceni kistérségben) pedig jellegükböl adódóan nem lehet ilyen társulást létrehozni.

Az elnyerhető források 2004-töl kezdve folyamatosan bővülni fognak. Míg 2004-ben pályázat útján 7,7 milliárd forint jutott a kistérségek többcélúvá alakulására, 2005-ben már 13,7 milliárd forint.

A leggyakrabban vállalt feladatok között említhető az iskolák, óvodák, különbözö települések által történő közös fenntartása (50 iskolabusz került beszerzésre); az orvosi-fogorvosi központok közös múködtetése (több mint 100 központi orvosi ügyelet került kialakításra), a családsegítés, valamint a mozgókönyvtári feladatok közös ellátása. Néhány társulás megyei feladatokat is átvállalt (pl. logopédia).

További célok között szerepel a kistérségek nagyobb szerephez jutása a decentralizációs folyamatokban, a kistérségi pályázatok előnyben részesítése a fejlesztési támogatások során, a kistérségek településszámból adódó problémáinak orvoslása.

A belügyminiszter a prezentációjának második felében a területfejlesztési szempontból leghátrányosabb helyzetü kistérségekröl beszélt. A leghátrányosabb helyzetủ kistérségek a területfejlesztés szempontjából kedvezményezett térségek közül azok, 
Tér és Társadalom 19. évf. 2005/3-4. 223-236. p.

amelyeknek komplex mutatója nem éri el Budapest komplex mutatójának a 60\%-át. Jelenleg 48 ilyen kistérség található hazánkban, amelyet a 64/2004-es kormányrendelet melléklete szabályoz. Ezek a kistérségek 2002-2004 között 80 milliárd Ft pályázati támogatásban részesültek, 2005-ben 3 millió Ft normatív és 1 millió Ft fejlesztési támogatást kaptak, míg 2006-ra 10 milliárd Ft-ot irányzott elő a kormányzat a leghátrányosabb helyzetü kistérségek felzárkóztatására.

Rechnitzer János, az MTA RKK Nyugat-magyarországi Tudományos Intézetének igazgatója „Kistérségek és a teriuleti tervezés" címmel tartott előadásában elsősorban a kistérségi tervezés hiányosságaira hívta fel a figyelmet, majd megfogalmazta javaslatait. Véleménye szerint nincs ma hazánkban egy egyértelmü jövőkép, a beavatkozások nem átgondoltak, a programok csak ötlethalmazok, melyben a mindenkinek jusson egy kicsi elv látszik érvényesülni. A források elosztásánál is laza fegyelem van, mely az Európai Unióban nem megengedett.

Javaslatában hangsúlyozta, hogy el kellene dönteni, mit nevezünk fejlesztésnek. Példaként hozta, hogy egy iskola fütésrendszerének kialakítása nem feltétlenül minösül ennek, míg két falu összekötö útjának megépítése annál inkább, hiszen az új út tereket nyit, új térbeli folyamatok indulhatnak meg. Ezenkívül kiemelte, hogy a tervezési rendszer egyértelművé tétele érdekében szükség van az egyes felek közötti hatékony kommunikációra és az együttes munkára; csak így lehet tudni kinek, mikor, mit kell tennie, nem fog elveszni a lényeg a részletekben.

Wiener György, a Debreceni Egyetem egyetemi docense fontosnak tartja, hogy a kistérségi tervezés rendszerében ne feledkezzenek meg a szakértők az önkormányzati rendszer fontosságáról. Kiemelte, hogy az önkormányzati hálózatok megőrzésére van szükség a hatékony tervezés érdekében.

Somlyódyné Pfeil Edit, az MTA RKK Dunántúli Tudományos Intézetének tudományos fömunkatársa a „Kistérségi közigazgatás a kutató szemével" címmel tartott elöadást. Elsőként arra hívta fel a figyelmet a kutatóasszony, hogy kistérségi (NUTS 4) szinten a közigazgatás-szervezés és a területfejlesztés intézményrendszerének összekapcsolása szuikséges. Maga a kistérség-központ (a város) és kistérsége közötti kapcsolat sok esetben nem tisztázott, hiszen a város is megjelenik ebben a rendszerben térségi, illetve önkormányzati egységként. Ennélfogva nemcsak a kistérségek fejlesztésével és kistérségi problémákkal kell foglalkozni, hanem ezzel párhuzamosan városfejlesztéssel is.

Megállapítása szerint a többcélú kistérségi társulások bevezetését differenciáltan kellett volna véghezvinni, ugyanis a bevezetéskor nem vették figyelembe a ruralitás/urbanitás indexet, hiszen hazánk kistérségei nem rurális jellegüek, általában a kistérségek egy-egy város körül helyezkednek el, mely fejlettségétől függően hat a környezó településekre.

Németh Jenő az IDEA Kistérségi Munkacsoport vezetője kiemelte, hogy egy Komplex Kistérségi Tervezési Kézikönyvre lenne szükség, melynek keretében megvalósítható lenne egy átlátható rendszer, melyben mindenki tudja kinek, milyen feladatai vannak, melyek a legfontosabb tervezési koncepciók. 
Az előadásokat követő vita legfontosabb üzenete az volt, hogy el kell dönteni mit kell fejleszteni: vidéket vagy várost, illetve régiót vagy kistérséget, mert egyszerre nem lehet mindenre koncentrálni és a források szétosztása is túlságosan elaprózódna, ha egyszerre mindent támogatni szeretnének. Ezenkívül hangsúlyozták, hogy a kistérségi együttmúködés önkéntes, és a kistérségekben vezető szerepet játszó városok feladata nem a vezetés, hanem a települések szervezése, együttmüködések kialakítása.

\section{Jegyzet}

${ }^{1}$ Forrás: A közigazgatási kistérség. (vitaanyag) www.b-m.hu/idea 2003. 